\title{
CONCEPTUAL FRAMEWORK FOR MANAGING THE FORMATION OF AN EFFECTIVE BUSINESS MODEL OF AN AIRLINE COMPANY
}

\author{
Zarina Poberezhna'
}

\begin{abstract}
The aim of the article is to develop and test the theoretical and methodological approach concerning the management of the formation of an effective airline business model based on its integral competitiveness indicator, which is a determining factor of survival in difficult and dynamic conditions, as well as the guiding vector of the enterprise development in the future. The method for assessing the competitiveness of the airline business model is based on a dualistic system of integrated indicators. The first integrated indicator provides a static assessment of the competitiveness of the airline business model compared to selected competitors, a reference company or average data for a particular market (local, regional, national). In order to assess the static component of the competitiveness of the business model of the airline company, as a method of constructing an integral indicator, the method of taxonomy was chosen, which best meets the condition of maximum objectivity in the calculations. The second integral indicator is responsible for the dynamic component of the assessment and shows the degree of synchronization of the company with the relevant market. Accordingly, will assess a set of financial, managerial and marketing indicators that characterize the results of both basic and management business processes of companies, taking into account the overall quality of business management processes. The information base of the study consists of data from financial statements of aviation enterprises of Ukraine. The sample size is 15 units. Methodology. The first stage of the analysis included the calculation of the share indicators of the competitiveness of the business model of the airlines according to the following criteria: "efficiency of production activities", "financial condition", "efficiency of marketing activities", and "quality of business processes". Further, the study calculated conditional (relative) indicators of competitiveness of the studied airlines by comparing the absolute measure of the enterprise with the best value of these indicators of all competitors in the market. On the basis of which the "matrix of competitive development" was built. Results of the study. According to the results of the construction of the "matrix of competitive development" the following four types of management business model development of the airline enterprises were formed: adaptive management, strategic management, anticipative management (there are no enterprises in this zone), anti-crisis management. Practical conclusions. The conducted research allowed to establish that the overall level of competitiveness of the business models of the studied airline companies is quite low, since there is not a single company in the most attractive zone of high competitiveness. Also, 6 of the 15 examined airlines are at a crisis stage of development, which actualizes the need to develop a set of anti-crisis measures to further stabilize the competitive position.
\end{abstract}

Key words: conceptual framework, methodology of business model evaluation, airline companies, theoretical and methodological approach to business model management, airline competitiveness, efficient business model, integral indicator of the competitiveness of the business model of the airline company, types of business model management.

\section{JEL Classification: M21, L93}

\section{Introduction}

The interest of airlines in the results of their activities increases the need to improve product competitiveness, which requires improvements in all services and

\footnotetext{
Corresponding author:

${ }^{1}$ National Aviation University, Ukraine.

E-mail: zarina_www@ukr.net

ORCID: https://orcid.org/0000-0001-6245-038X

ResearcherID: T-8659-2018
}

departments of business units. Competitiveness is the most important factor in ensuring the safety of the airline company, i.e. survival and effective further development. An integrated approach to the 
development and construction of the competitiveness model of the airline company acquires particular relevance in today's conditions, because it can serve as a tool for solving strategic tasks to improve competitiveness. Despite a number of studies in the field of assessing the competitiveness of the enterprise, allowing to carry out the assessment using matrix methods (Miroshnyk, Kobjeljev, 2014; Nykoljuk, 2011; Shevchenko, 2018; Metodychni...) and methods based on the theory of effective competition (Ghorbalj, Sukhorsjka, 2012; Skoroboghatova, Gherghelj, 2014) an objective need arose to develop a system for assessing the competitiveness of the business model of the airline company, which would combine the statistical and dynamic component of companies and minimize the weight of expert evaluations in its implementation process.

The aim of the article is to develop and test the theoretical and methodological approach to managing the formation of the effective business model of an airline company on the basis of its integral competitiveness indicator. Accordingly, the objectives of the study are as follows: to generalize existing approaches to assessing the competitiveness of enterprises, to identify shortcomings for the application of these methodologies to assess the competitiveness of business models of aviation enterprises, to develop our own theoretical and methodological research approach in the problem area and its validation.

\section{Instrumental ensuring methods for assessing the competitiveness of the enterprise}

Enterprise competitiveness is understood as competition for the best results, which is impossible without the accumulation and use of all available potential capabilities of the company and its individual components, namely: resources, human skills, technology, efficiency (productivity, profitability and effectiveness) (Shevchenko, 2018 Istorychna ... ).

Mathematical modeling can be a tool for assessing the competitiveness of the enterprise, allowing you to identify the features of the economic object and on this basis to anticipate the future behavior of any changes in the parameters of the business model.

Modern economics offers a number of quantitative tools for such analysis, including the best-known measures of concentration of production, the Herfindahl-Hirschman Index and several other indicators that basically determine competitors' market share, profitability and market growth (Kokura, 2013).

The most popular methods for assessing competitiveness include the following (Miroshnyk, Kobjeljev, 2014; Nykoljuk, 2011; Shevchenko, 2018 Metodychni...):
1. The matrix method. The basis of this method is an analysis of competitiveness, taking into account the life cycle of the product / service. The essence of the assessment is to analyze the matrix, based on the principle of constructing a system of coordinates, where the horizontal line is responsible for the growth/decrease in sales on a linear scale, and the vertical line is the relative share of goods/services in the market. The most competitive companies are those that have a significant share of the fast-growing market.

2. A method based on the theory of effective competition. According to this theory, the most competitive enterprises are those in which the work of all departments and services is better organized. The method is based on an assessment of four group indicators (criteria) of competition, namely: the first group includes indicators characterizing the effectiveness of management of the production process; the second group includes indicators reflecting the effectiveness of working capital management; the third group is indicators, which give an idea of the effectiveness of sales management and promotion of goods in the market through advertising and promotion; the fourth group includes indicators of product competitiveness (product quality, service, price). Since each of these indicators has a different value for calculating the coefficient of competitiveness of the enterprise, the weighting coefficients of the criteria are calculated by expert-based method (Ghorbalj, Sukhorsjka, 2012; Skoroboghatova, Gherghelj, 2014).

To make management decisions as part of the basic analysis of the company can use the index of their integrated competitiveness. However, there are a number of problems with the application of this index, which are associated with the methodological difficulties of its quantitative calculation, leading to a very wide use of expert evaluations, so the adequacy of the results of calculations raises certain doubts.

The authors substantiate different groups of factors that should be included in the aggregate (integral, group) indicator, depending on the field of study and on the basis of their scientific point of view. In addition, different methods of making an expert conclusion are offered, and it is often simply said that "the scales are defined expertly" (Zotova, 2012; Kabaljsjka, 2013).

\section{Development of a theoretical and methodological approach to managing the formation of the effective business model of the airline company}

To assess the competitiveness of the business model of the airline company, lets form a methodological basis for determining its integral competitiveness, which would exclude expert estimates as a result of 
calculations based on the available information about the activities of the company. First, it should be noted that any calculated efficiency of the airline company is an index that characterizes its potential, which, for one reason or another, may not be realized. The established result of the airline company's activity, which is subject to observation and measurement, is the actual result. Given this observation, one way or another, the calculated competitive indicator of the airline company characterizes its competitive potential. And the real competitiveness of the business model of the airline company manifests itself only in the market.

In determining a possible algorithm for assessing the competitiveness of the business model of the airline company should be based on the following two main characteristics of this indicator (Shevchenko, 2013 Suchasni ... ; Jackovyj, 2013):

1) Compatibility. It is impossible to assess the competitiveness of the airline business model solely on the basis of the analysis of its indicators. A prerequisite of this assessment is a comparison of performance, namely the studied index with competitors, standards, benchmarks or average values for a set of objects;

2) Fixation in time. The results of assessing the competitiveness of the business model of the airline company have brief relevance. This is a derivative feature, changes in the achieved competitiveness of the business model of the airline company are influenced not only by the efficiency of its operations, but also by the actions of competitors and the general situation in the market.

The development of a sequence of assessing the competitiveness of the business model of the airline company should be based on a number of principles, objective (regardless of the subject) and subjective (taking into account the specifics of the subject and the needs of the final recipients) assessment results. Objective principles include complexity, systematization, and validity. Compliance with subjective principles, in turn, depends on the type of end user, information and complexity of the enterprise under study. The final recipients of the results of assessing the competitiveness of the airline business model include the following groups: internal (management, analysts), and external (owners, potential investors, competitors, consumers, etc.). Each of these groups has specific objectives regarding the assessment of the competitiveness of the airline business model, and their requirements for the assessment methodology may differ in terms of time and material costs, given all the number of objects, simplicity of calculations, etc. The subjective principles of constructing a methodology for assessing the competitiveness of the airline business model include (Kokura, 2013; Shevchenko, 2018 Konkurentnyj... ):

a) Dynamicity. Despite this characteristic of the competitiveness of the airline business model "fixation in time", most clientele want the results of a retrospective analysis of the competitive position of the enterprise in the market, which encourages the search for a harmonized methodology to meet the needs of clientele. It should be noted that such a category of clientele, as consumer, often requires sufficient one-time determination of the competitiveness of the business model of the company;

b) Optimality. It is manifested both in the careful selection of indicators to be analyzed to avoid duplication, redundancy, excessive complexity and detail, and in the methods for analyzing these indicators;

c) Expenses. The expenditures for assessing the competitiveness of the airline business model must be reasonably correlated with the impact achieved by implementing the results of this assessment.

So, the development of the methodology for assessing the competitiveness of the business model of the airline company needs to form the following list of requirements (Serghijenko, Tatar, 2012):

1) maximum avoidance of subjectivity in the analysis of indicators;

2) a combination of assessing the company's competitiveness at a particular point in time with a dynamic assessment of the characteristics that determine the competitive position of the company and are characterized by comparability over time;

3) accounting for the quality of business process management at the enterprise;

4) use of quantitative indicators;

5) a basis for comparison.

A generalized sequence of stages of assessing the level of competitiveness of the airline business model is shown in Figure 1.

The proposed methodology for assessing the competitiveness of the airline business model is based on a dualistic system of integrated indicators. The first integral indicator provides a static assessment of the competitiveness of the airline business model compared to selected competitors, a reference company or average data for a particular market (local, regional, national). The second integral indicator is responsible for the dynamic component of the assessment and shows the degree of synchronization of the company with the relevant market (Figure 2).

To evaluate the static component of the competitiveness of the business model of the airline company the method of taxonomy was chosen, which best meets the condition of maximum objectivity in the calculations. The considering of the components of the integral index is usually determined by the expert method, which is characterized by one of the highest degrees of subjectivity (Shevchenko, 2018 Konkurentnyj... ). With the help of the taxonomy method it is possible to take into account the different impact of indicators on the level of the competitiveness 


\begin{tabular}{|c|c|}
\hline \multicolumn{2}{|c|}{$\begin{array}{l}\text { 1. Formation of the goal of assessing the competitiveness of the business model } \\
\text { of the airline companies }\end{array}$} \\
\hline \multicolumn{2}{|c|}{ 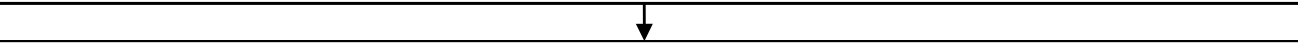 } \\
\hline \multicolumn{2}{|c|}{$\begin{array}{l}\text { 2. Analysis of existing methods for assessing the competitiveness of the business model } \\
\text { of the airline enterprises }\end{array}$} \\
\hline \multicolumn{2}{|c|}{$\downarrow$} \\
\hline \multicolumn{2}{|c|}{$\begin{array}{l}\text { 3. Identification of key areas of the competitiveness of the business model } \\
\text { of the airline companies }\end{array}$} \\
\hline \multirow{2}{*}{$\begin{array}{l}\text { Industrial } \\
\text { potential }\end{array}$} & Marketing \\
\hline & potential \\
\hline \multirow{2}{*}{$\begin{array}{l}\text { Financial } \\
\text { potential }\end{array}$} & Potential of internal business \\
\hline & processes \\
\hline \multicolumn{2}{|c|}{$\begin{array}{l}\text { 4. Establishing partial indicators within certain components of assessing the competitiveness } \\
\text { of the business model of the airline companies }\end{array}$} \\
\hline \multicolumn{2}{|c|}{$\downarrow$} \\
\hline \multicolumn{2}{|c|}{$\begin{array}{l}\text { 5. Formation of a matrix of values of partial indicators to assess the level } \\
\text { of the competitiveness of the business model of the airline companies }\end{array}$} \\
\hline \multicolumn{2}{|c|}{$\downarrow$} \\
\hline \multicolumn{2}{|c|}{$\begin{array}{l}\text { 6. Standardization of certain values of partial indicators on the basis of determining the relative } \\
\text { assessment of each of them as a result of dynamic development }\end{array}$} \\
\hline \multicolumn{2}{|c|}{ 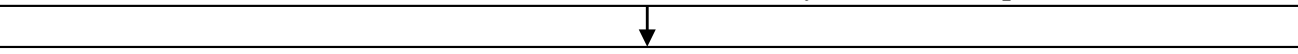 } \\
\hline \multicolumn{2}{|c|}{$\begin{array}{l}\text { 7. Calculation of weights of significance of partial indicators within the framework of } \\
\text { component assessment of the competitiveness of the business model of the airline companies }\end{array}$} \\
\hline \\
\hline \multicolumn{2}{|c|}{$\begin{array}{l}\text { 8. Determination of partial integral indicators, reflecting the level of components } \\
\text { of the competitiveness of the business model of the airline companies }\end{array}$} \\
\hline \multicolumn{2}{|c|}{$\downarrow$} \\
\hline \multicolumn{2}{|c|}{$\begin{array}{l}\text { 9. Determination of a general integral indicator for assessing the level of the } \\
\text { competitiveness of the business model of the airline companies }\end{array}$} \\
\hline \multicolumn{2}{|r|}{ 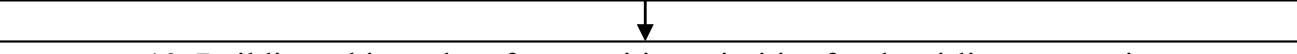 } \\
\hline 10. Buildin & the airline companies \\
\hline
\end{tabular}

Figure 1. Stages of the business model competitiveness assessment in the airline company

Source: designed by the author

of the business model of the airline company in the application of hierarchical coefficients, the calculation of which is also based on the methods of qualitative assessment, which increases the subjectivity of the developed methodology. For the current study, the positive effect of the taxonomy overcomes the need to differentiate the effect of the components on the integral index.

The choice of the system of indicators is based on the study of the methods and techniques for assessing the competitiveness of the business model of the airline company, as well as approaches to assessing the quality of management of business processes of the airline company. The proposed integral indicator, i.e. the development level indicator, will assess a set of financial, managerial and marketing indicators characterizing the results of both basic and equally important managerial business processes, some significant service business processes at the airline, taking into account the overall quality of business management processes.

Consequently, the integral coefficient of competitiveness of the airline business model, which determines the degree of its attractiveness for the buyer, usually combines the following potentials and resulting indicators (Table 1 ).

Having analyzed the aforementioned information, it can be seen that the proposed competitiveness evaluation system covers only a small part of the indicators that can assess the level and state of the competing enterprises. The problem with using an integrated indicator of the competitiveness is that it is 


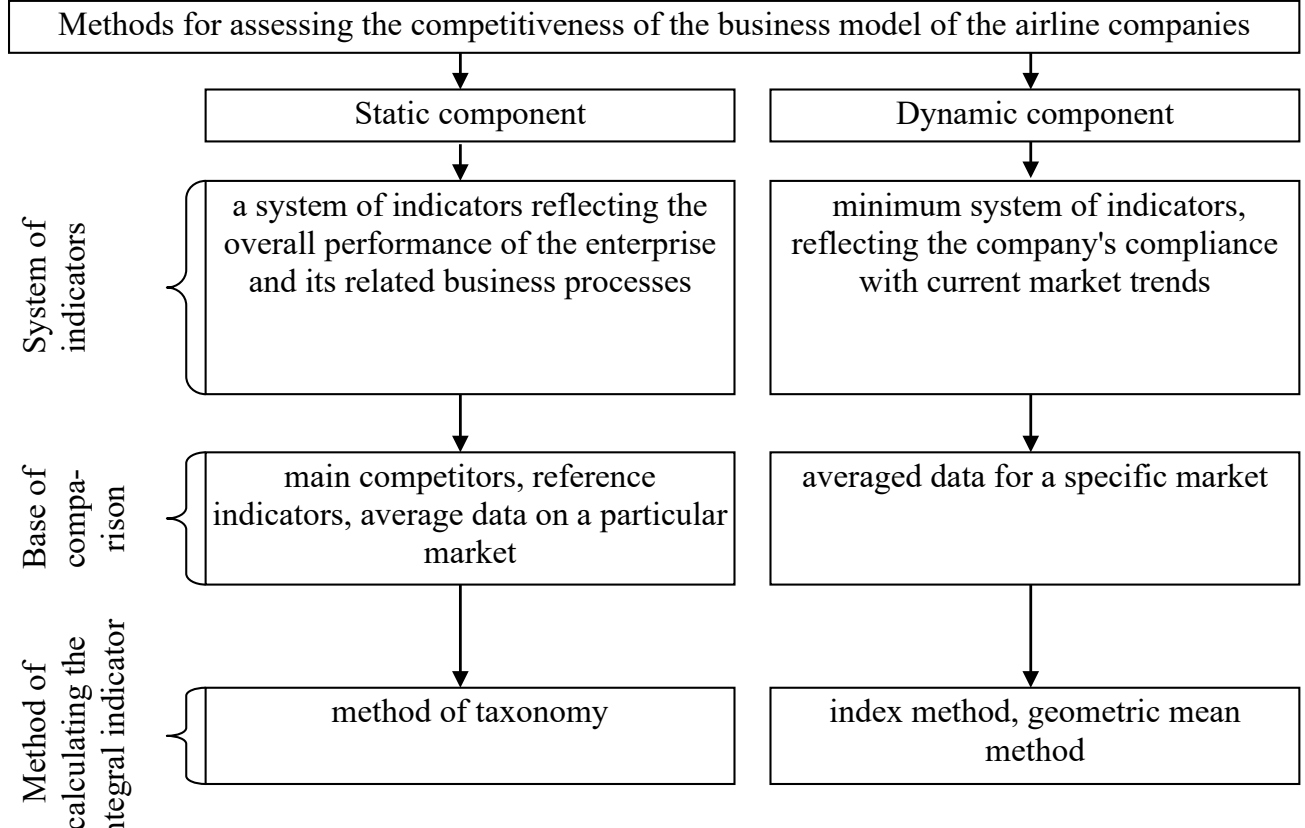

Figure 2. Methodology for assessing the competitiveness of the airline business model

Source: designed by the author

impossible to identify several relevant determinants. However, it is possible to identify indicators that best reflect the level of the competitiveness of the enterprise and reveal its activities (Kotvicjkyj, 2009).

Since each of the calculated indicators has a different value for calculating the coefficient of the competitiveness of the business model of the airline enterprises (CCE), the weights of each criterion and indicator were set by experts. The calculation of the criteria and the coefficient of the competitiveness of the enterprise is carried out according to the formula of the weighted arithmetic mean (Tranchenko, 2013).

For example, applying this formula to the coefficient of the competitiveness of the business model of the airline we get the following expression (Kabaljsjka, 2013, Shynkar S.M., 2011):

$$
\begin{aligned}
& C C E=0,15 \times C e p a+0,29 \times C f c+0,23 \times \\
& \times C e m a+0,33 \times C q b p
\end{aligned}
$$

where CCE - the coefficient of the competitiveness of the business model of the airline enterprises; Cepa - the value of the criteria of efficiency of the production activities of the enterprise; $C f_{\mathcal{c}}$ - the value of the criteria of the financial condition of the enterprise; Cema - the value of the criteria of effectiveness of the marketing activities; $C q b p$ - the value of the criteria of quality of the business processes. The coefficients $0.15 ; 0.29 ; 0.23 ; 0.33$ were determined expertly by successive comparisons.

The proposed methodology for assessing the integral indicator of the competitiveness of the competing enterprises on the basis of the key performance indicators, which can optimally assess the real level of the competing enterprises in the current economic environment.

In order to calculate the integral indicator "criteria of the production efficiency" of the airline company is proposed to evaluate the following partial indicators: yield on capital investments, return on assets, rate of return on operating activities, labor productivity. The criteria for the effectiveness of the production activities of the airline company is determined by the formula (Kabaljsjka, 2013; Shynkar, 2011):

$$
\text { Cерa }=0,31 \times C i+0,19 \times R O A+0,40 \times R o a+0,10 \times L p
$$

Table 1

Input data for estimation of integral coefficient of the competitiveness of the airline business model (CCE)

\begin{tabular}{|l|c|}
\hline \multicolumn{1}{|c|}{ Indicator } & Sensitivity coefficient \\
\hline 1. The criteria for the effectiveness of production activities & 0,15 \\
\hline 2. The financial condition criteria & 0,29 \\
\hline 3. The criteria for the effectiveness of marketing activities & 0,23 \\
\hline 4. The criteria for the quality of the business processes & 0,33 \\
\hline
\end{tabular}

Source: designed by the author 
where Cepa - criteria of efficiency of production activity; $C i$ - yield on capital investments; ROA return on assets; Roa - rate of return on operating activities; $L p$ - labor productivity. The coefficients $0.31 ; 0.19 ; 0.40 ; 0.10$ were determined expertly by successive comparisons.

Calculation of the integral indicator "criteria of financial condition" of the airline company is proposed to evaluate the following share indicators: equity to total assets ratio, solvency ratio, absolute liquidity ratio, turnover ratio of current assets. The criterion of financial condition is determined by the formula (Kabaljsjka, 2013; Shynkar, 2011):

$$
C f c=0,29 \times E r+0,20 \times S r+0,36 \times L r+0,15 \times \operatorname{Trca}
$$

where $C f c$ - criteria of financial condition; $C a$ equity to total assets ratio; $S r$ - solvency ratio; $L r-$ absolute liquidity ratio; $\operatorname{Trca}$ - turnover ratio of current assets. The coefficients $0.29 ; 0.20 ; 0.36 ; 0.15$ were determined expertly by successive comparisons.

To calculate the integral indicator "criteria of marketing activity efficiency" of the airline company it is proposed to estimate the following share indicators: return on sales, profitability ratio of sales costs, ratio of change in sales volume, product profitability ratio. The criteria for the effectiveness of the marketing activities will be determined by the formula (Kabaljsjka, 2013; Shynkar, 2011):
Cema $=0,37 \times R O S+0,29 \times R p s c+0,14 \times$

$\times R c s v+0,2 \times P p r$

where Cema - criteria for the effectiveness of the marketing activities; ROS - return on sales; Rpsc profitability ratio of sales costs; Rcsv - ratio of change in sales volume; $\mathrm{Ppr}$ - product profitability ratio. The coefficients $0.37 ; 0.29 ; 0.14 ; 0.20$ were determined expertly by successive comparisons.

Having analyzed the above information, we can see that this system of evaluating the competitiveness of the airline business model covers only a small part of the indicators that could evaluate the level and condition of the competing airlines. The problem with using an integrated indicator of the competitiveness of the airline business model is that it is impossible to identify several determinants. However, we can identify those indicators that best reflect the competitiveness of the airline business model and reveal its activities.

To return to the system of the indicators for the static assessment of the competitiveness of the business model of the airline company, the indicator of "the quality of business process management" is worth special attention. Quantitative assessment of the criterion "quality of business process management" is possible on the basis of a score system (Figure 3).

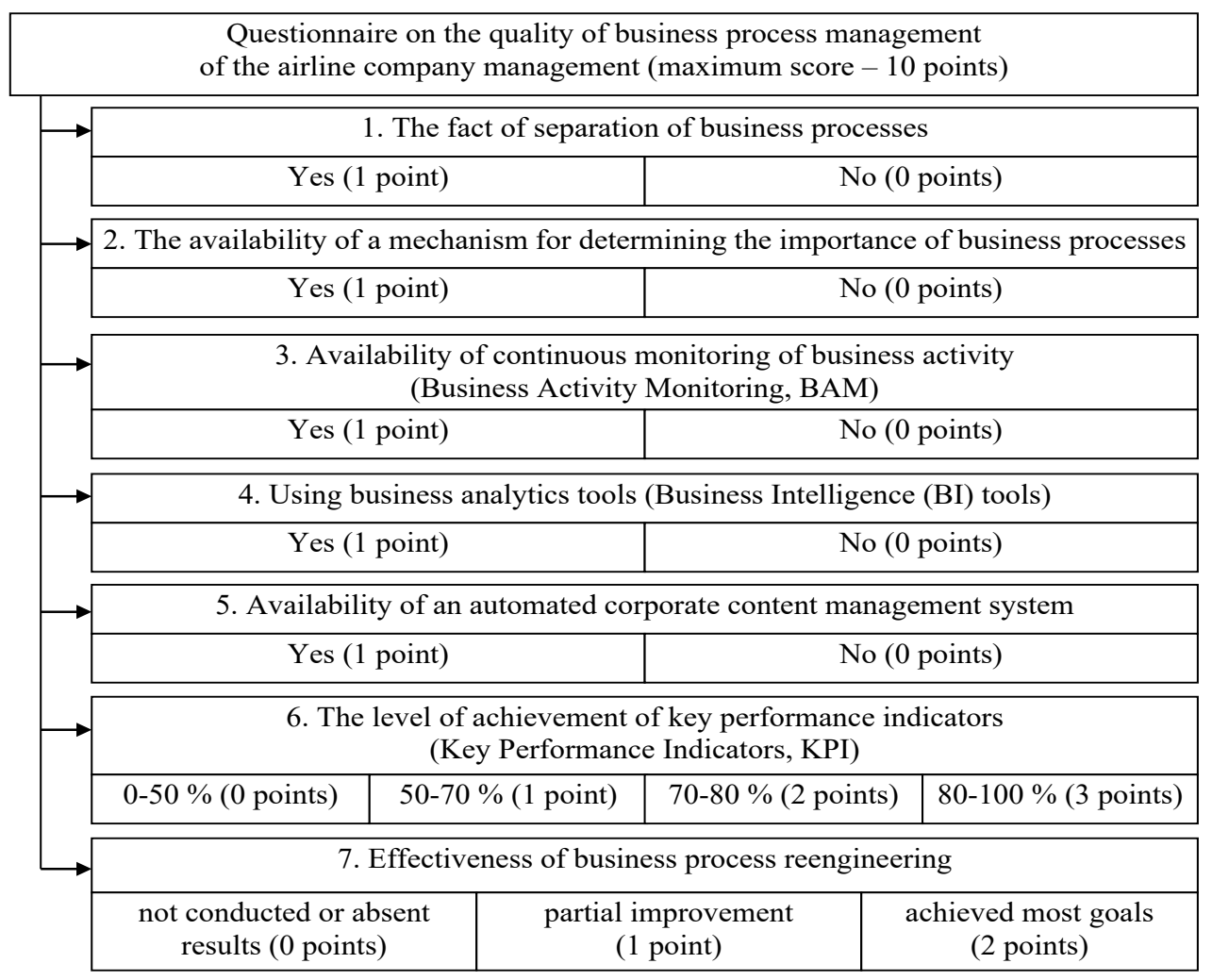

Figure 3. System of indicators for assessing the quality criteria of business process management $(\mathrm{Cq} b \mathrm{p})$ in the airline enterprises

Source: designed by the author 


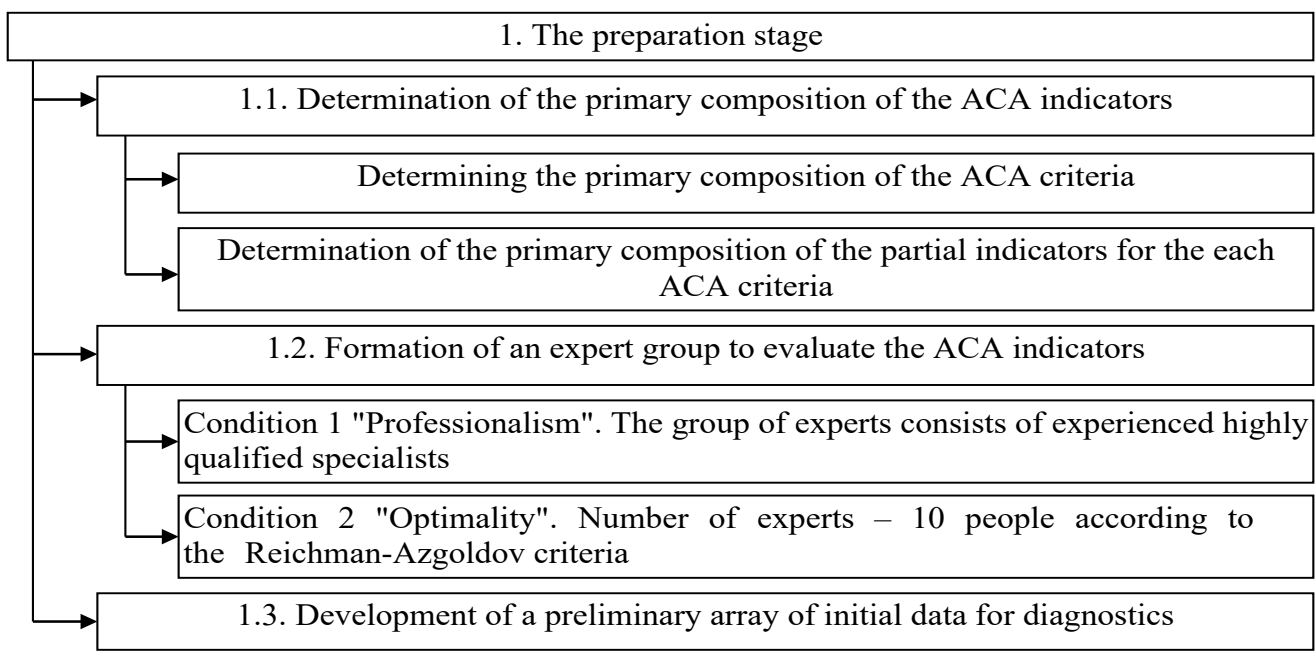

Figure 4. The preparation stage of business model competitiveness assessment for the airline company Source: designed by the author

Considering the above, the author proposed a theoretical and methodological approach to managing the formation of the effective business model of the airline company, the main stages of which are presented in Figure 4-6. The preparatory stage of assessing the competitiveness of the business model of the airline enterprises (ACA) is presented in Figure 4.

The calculation stage of assessing the competitiveness of the business model of the airline enterprises (ACA) is presented in Figure 5.

The analytical stage of assessing the competitiveness of the airline business model is presented in Figure 6.

The analytical stage of assessing the competitiveness of the airline business model should be considered the central stage of the developed approach. In particular, at this stage it is advisable to carry out the identification of relevant indicators, such as:
1. Identification of the level of the competitiveness of the airline business model by the $\mathrm{I}_{\mathrm{CCE}}$ value. In this case, the distribution of the level of competitive development of the enterprise is proposed to carry out on the following scale:

- High level of CCE $\left(0,67<\mathrm{I}_{\mathrm{CCE}}<1\right)$;

- Intermediate level of CCE $\left(0,34<\mathrm{I}_{\mathrm{CCE}}<0,66\right)$;

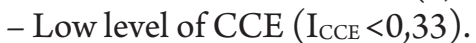

2. Identification of the stage of the life cycle of the airline company by the indicator of the intensity of sales (ratio of change in sales volume $-R_{c s v}$ ). Thus the corresponding values of the indicator Rcsv are calculated in the dynamics for at least two years in order to be able to reflect the nature of changes in the sales volume of the enterprise (increasing or decreasing).

According to the results of the analytical stage of the identification of the level of the competitiveness of the business model of the airline company according

\begin{tabular}{|c|}
\hline 2. The calculation stage \\
\hline 2.1. Formation of the final list of indicators of CCE and a data set \\
\hline 2.2. Calculation of partial indicators of CCE estimation \\
\hline 2.3. Calculation of integrated indicators (criteria) of the CCE: \\
\hline Cepa $=0,31 \times C i+0,19 \times R O A+0,40 \times R o a+0,10 \times L p$ \\
\hline$C f c=0,29 \times C a+0,20 \times S r+0,36 \times L r+0,15 \times \operatorname{Trca}$ \\
\hline Cema $=0,37 \times R O S+0,29 \times R p s c+0,14 \times R c s v+0,2 \times P p r$ \\
\hline $\begin{array}{l}\text { 2.4. Calculation of the integrated indicator of competitiveness of the business model of } \\
\text { the aviation enterprises (CCE) }\end{array}$ \\
\hline$C C E=0,15 \times C e p a+0,29 \times C f c+0,23 \times C e m a+0,33 \times C q b p$ \\
\hline
\end{tabular}

Figure 5. The calculation stage of the airline business model competitiveness assessment Source: designed by the author 


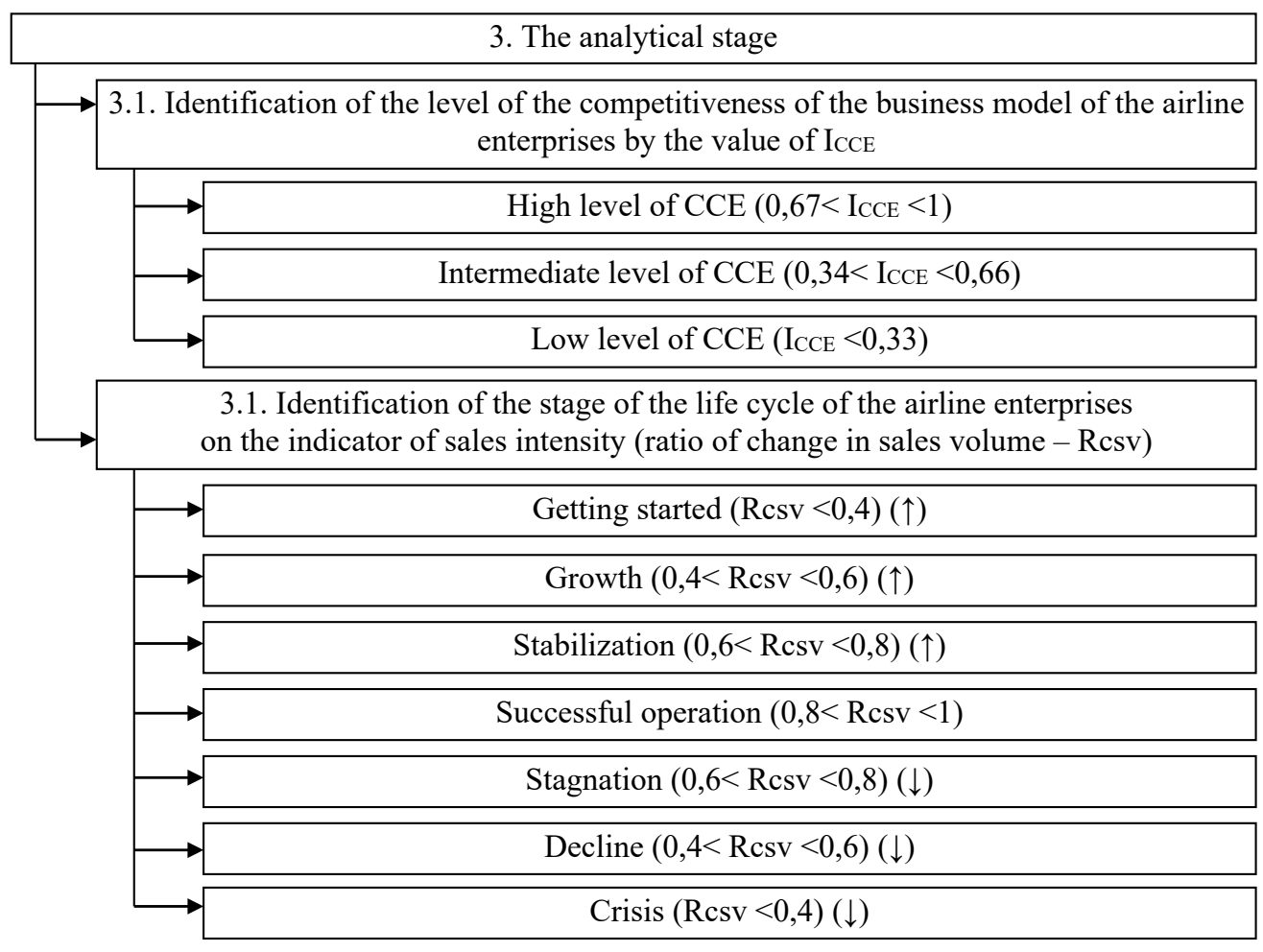

Figure 6. The analytical stage of assessing the competitiveness of the airline business model

to the value (ICCE) and the identification of the life cycle stage of the airline company according to the indicator of the intensity of sales (ratio of change in sales volume - $R_{\text {csv }}$ ) the corresponding values of indicators of the competitive development of the company should be positioned. There are 21 quadrants, each of which can be attributed to a particular type of the business model management system:

1. Adaptive business model management (quadrants $1,2,3,4,5,6)$.

2. Strategic business model management (quadrants $7,8,9,10,11,12$ ).

3. Anticipative business model management (quadrants 13, 14, 15, 16, 19).

4. Anti-crisis management of the business model (quadrants 17, 18, 20, 21).

So, the proposed methodology is a synthesis of expert, matrix and integral approaches to assessing the competitiveness of the business model of the airline company and additionally takes into account the identified features of assessing the competitiveness of the subjects of the airline industry.

\section{Practical implementation of the theoretical and methodological approach to assessing the competitiveness of the business model of the airline company}

To confirm the practical value of the developed methodology for assessing the competitiveness of the business model of the airline companies, its approbation is necessary.

The information base of the study was the data from the financial statements of the airline companies of Ukraine. The sample volume is 15 units.

It is also necessary to calculate the conditional (relative) indicators of the competitiveness of the examined airlines companies. According to the methodology of the effective competition theory, the relative indicators of the competitiveness of the airline business model are determined by comparing the absolute measures of the airline with the best value of these indicators of all competitors in the market.

The following integral indexes of the CCE $\left(\mathrm{I}_{\mathrm{CCE}}\right)$ were obtained based on the results of the integral assessment of the competitiveness of the business model of the airline companies of Ukraine: the first company shows -0.364 ; the 2 nd -0.437 ; the 3 rd 0.295 ; the 4th -0.364 ; -0.193 ; the 5 th -0.336 ; the 6th $-0,244$; the 7th $-0,276$; the 8 th $-0,505$; the 9th 0,430 ; the 10th $-0,398$; the 11 th $-0,243$; the 12 th 0,304 ; the 13 th $-0,402$; the 14 th $-0,265$; the 15 th 0,425 .

It should be noted that almost all of the studied airlines received mediocre values of integral indices of the competitiveness, which indicates the existing problems of formation and development of the business model, optimal to external and internal conditions of management. 


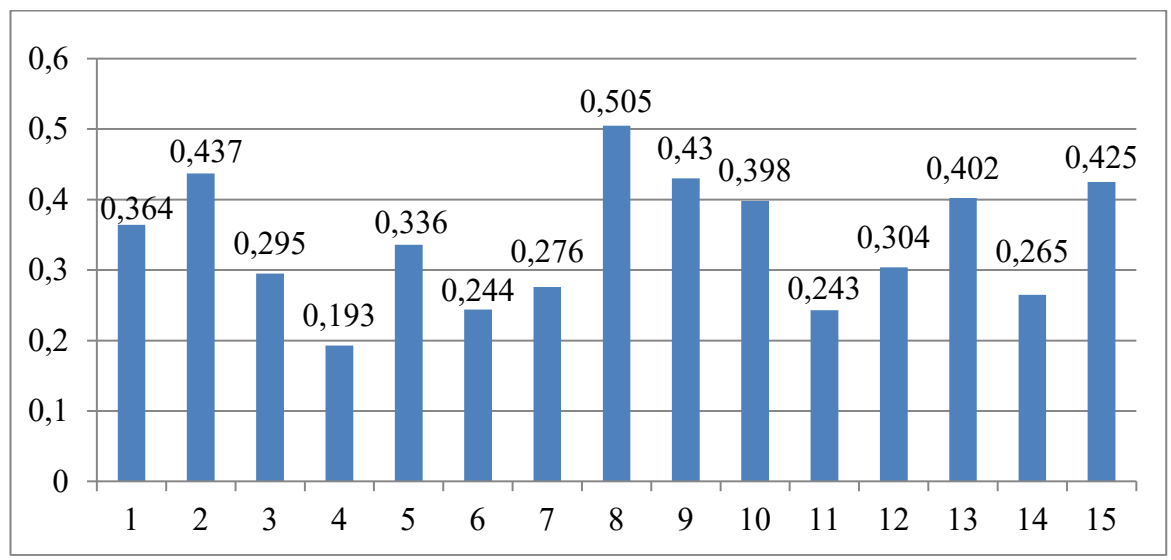

Figure 7. The value of the integral indicator of the competitiveness of the business model of the surveyed airline enterprises ( $\mathbf{I}_{\mathrm{CCE}}$ ) in 2019

Source: designed by the author

The obtained values of the integral indicator of the competitiveness of the business model of the studied airline enterprises ( $\mathrm{I}_{\mathrm{CCE}}$ ) are presented in Figure 7.

Consequently, according to the data of Figure 7 it can be stated that the most competitive are the airlines under № 4, 6, 7, 11, 14, because the obtained indicators of their integral indexes $\left(\mathrm{I}_{\mathrm{CCE}}\right)$ have an extremely low value. At the same time, the leaders in the level of competitiveness were the airlines № $2,8,9,10,13,15$ with sufficiently high values of integral indices $\left(\mathrm{I}_{\mathrm{CCE}}\right)$.

In order to identify the stage of the life cycle of a particular airline company, it is necessary to calculate the ratio of change in sales volume (Rcsv) in the dynamics for two years (2018-2019). The results of the identification of the stage of the life cycle of the airline by the ratio of change in sales volume (Rcsv) are presented in Table 2.

Consequently, the calculated values of the ratio of change in sales volume (Rcsv) are necessary for further positioning of the each airline company on the "matrix of competitive development". At the same time, the established trends in the volume of sales reflect the dynamics of enterprises on the market (increasing or decreasing).

The results of the positioning of the examined airlines in the corresponding quadrants of the "competitive development matrix" with the identification of the appropriateness of the relevant type in the management of their business model are presented in Figure 8.

Table 2

The results of the identification of the stage of the life cycle of the airline by the ratio of change in sales volume (Rcsv)

\begin{tabular}{|c|c|c|c|c|c|}
\hline \multirow{2}{*}{ Company } & \multirow{2}{*}{$\begin{array}{c}\text { Ratio of change in sales } \\
\text { volume - (Rcsv) }\end{array}$} & \multicolumn{2}{|c|}{ Sales volume, thousand UAH } & \multirow{2}{*}{$\begin{array}{l}\text { The difference between } \\
2018 \text { and } 2019 \text {. }\end{array}$} & \multirow{2}{*}{ Trend in sales volumes } \\
\hline & & 2018 & 2019 & & \\
\hline 1 & 0,337 & 10387 & 6011 & -4376 & $(\downarrow)$ \\
\hline 2 & 0,138 & 1679318 & 398401 & -1280917 & $(\downarrow)$ \\
\hline 3 & 0,611 & 5569 & 5836 & 267 & $(\uparrow)$ \\
\hline 4 & 0,591 & 4497693 & 4561181 & 63488 & $(\uparrow)$ \\
\hline 5 & 0,654 & 349261 & 392176 & 42915 & $(\uparrow)$ \\
\hline 6 & 0,557 & 9792 & 9357 & -435 & $(\downarrow)$ \\
\hline 7 & 1,000 & 30763 & 52782 & 22019 & $(\uparrow)$ \\
\hline 8 & 0,015 & 6584 & 172 & -6412 & $(\downarrow)$ \\
\hline 9 & 0,135 & 1590713 & 367533 & -1223180 & $(\downarrow)$ \\
\hline 10 & 0,653 & 29033 & 32528 & 3495 & $(\uparrow)$ \\
\hline 11 & 0,624 & 4106 & 4396 & 290 & $(\uparrow)$ \\
\hline 12 & 0,585 & 38683 & 38851 & 168 & $(\uparrow)$ \\
\hline 13 & 0,341 & 118 & 69 & -49 & $(\downarrow)$ \\
\hline 14 & 0,828 & 2174210 & 3088113 & 913903 & $(\uparrow)$ \\
\hline 15 & 0,329 & 478162 & 270172 & -207990 & $(\downarrow)$ \\
\hline
\end{tabular}

Source: designed by the author 


\begin{tabular}{|c|c|c|c|c|c|c|c|c|}
\hline \multirow{5}{*}{ 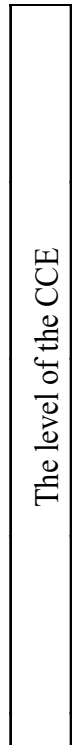 } & $\begin{array}{c}\text { High } \\
(0,67-1,00)\end{array}$ & $\begin{array}{c}\text { Quadrant } \\
1\end{array}$ & $\begin{array}{c}\text { Quadrant } \\
4\end{array}$ & $\begin{array}{c}\text { Quadrant } \\
7\end{array}$ & $\begin{array}{c}\text { Quadrant } \\
10\end{array}$ & $\begin{array}{c}\text { Quadrant } \\
13\end{array}$ & $\begin{array}{c}\text { Quadrant } \\
16\end{array}$ & $\begin{array}{c}\text { Quadrant } \\
19\end{array}$ \\
\hline & $\begin{array}{c}\text { Medium } \\
(0,34-0,66)\end{array}$ & $\begin{array}{c}\text { Quadrant } \\
2\end{array}$ & $\begin{array}{c}\text { Quadrant } \\
5\end{array}$ & $\begin{array}{c}\text { Quadrant } \\
8\end{array}$ & $\begin{array}{c}\text { Quadrant } \\
11\end{array}$ & $\begin{array}{c}\text { Quadrant } \\
14\end{array}$ & $\begin{array}{c}\text { Quadrant } \\
17\end{array}$ & Quadran \\
\hline & $\begin{array}{c}\text { Low } \\
(0-0,33)\end{array}$ & $\begin{array}{l}\text { Quadrant } \\
3\end{array}$ & $\underset{6}{\text { Quadr }}(12$ & $\begin{array}{l}\text { Quadrant } \\
3)^{9}\end{array}$ & Quadrant & $\begin{array}{c}\text { Quadrant } \\
15\end{array}$ & Quadrant 18 & $\begin{array}{l}\text { Quadrant } \\
21\end{array}$ \\
\hline & & $\begin{array}{c}\text { Begin- } \\
\text { ning } \\
(0-0,40)\end{array}$ & $\begin{array}{l}\text { Growth } \\
(0,41- \\
0,60)\end{array}$ & $\begin{array}{c}\text { Stabili- } \\
\text { zation } \\
(0,61- \\
0,80)\end{array}$ & $\begin{array}{c}\text { Success- } \\
\text { ful } \\
\text { operation } \\
(0,81- \\
1,00) \\
\end{array}$ & $\begin{array}{c}\text { Stagna- } \\
\text { tion } \\
(0,61- \\
0,80)\end{array}$ & $\begin{array}{c}\text { Decline } \\
(0,41- \\
0,60)\end{array}$ & $\begin{array}{l}\text { Crisis } \\
(0-0,40)\end{array}$ \\
\hline & \multicolumn{8}{|c|}{$\begin{array}{c}\text { Life cycle stages (Rcsv) } \\
\end{array}$} \\
\hline \multicolumn{2}{|r|}{ Company } & \multicolumn{3}{|c|}{$\begin{array}{c}\text { Ratio of change in sales } \\
\text { volumes (Rcsv) }\end{array}$} & \multicolumn{2}{|c|}{$\begin{array}{c}\text { Integrated } \\
\text { Competitiveness } \\
\text { Indicator (ICCE) }\end{array}$} & \multicolumn{2}{|c|}{$\begin{array}{c}\text { The trend of } \\
\text { changes in sales }\end{array}$} \\
\hline \multicolumn{2}{|r|}{1} & \multicolumn{3}{|c|}{0,337} & \multicolumn{2}{|c|}{0,364} & \multicolumn{2}{|c|}{$(\downarrow)$} \\
\hline \multicolumn{2}{|r|}{2} & \multicolumn{3}{|c|}{0,138} & \multicolumn{2}{|c|}{0,437} & \multicolumn{2}{|c|}{$(\downarrow)$} \\
\hline \multicolumn{2}{|r|}{3} & \multicolumn{3}{|c|}{0,611} & \multicolumn{2}{|c|}{0,295} & \multicolumn{2}{|c|}{$(\uparrow)$} \\
\hline \multicolumn{2}{|r|}{4} & \multicolumn{3}{|c|}{0,591} & \multicolumn{2}{|c|}{0,193} & \multicolumn{2}{|c|}{$(\uparrow)$} \\
\hline \multicolumn{2}{|r|}{5} & \multicolumn{3}{|c|}{0,654} & \multicolumn{2}{|c|}{0,336} & \multicolumn{2}{|c|}{$(\uparrow)$} \\
\hline \multicolumn{2}{|r|}{6} & \multicolumn{3}{|c|}{0,557} & \multicolumn{2}{|c|}{0,244} & \multicolumn{2}{|c|}{$(\downarrow)$} \\
\hline & 7 & & 1,000 & & & & & \\
\hline & 8 & & 0,015 & & & & & \\
\hline & 9 & & 0,135 & & & & & \\
\hline & 10 & & 0,653 & & & & & \\
\hline & 11 & & 0,624 & & & & & \\
\hline & 12 & & 0,585 & & & & & \\
\hline & 13 & & 0,341 & & & & & \\
\hline & 14 & & 0,828 & & & & & \\
\hline & 15 & & 0,329 & & & & & \\
\hline
\end{tabular}

Figure 8. The results of the positioning of the studied airlines on the "competitive development matrix" Source: designed by the author

The result of the study was the positioning of the each airline company in the corresponding quadrants of the "matrix of competitive development", which allowed to propose different types of the business model management system of the airline company (Figure 9). Thus, four types of airline business model management templates were formed, namely:

- Adaptive management template for enterprises № 4, 12;

- Strategic business management template for enterprises № 3, 5, 7, 10, 14;

- Anticipative business management template (there are no enterprises in this field);

- Anti-crisis management template for enterprises № $1,2,6,8,9,13,15$.

On the basis of which it was found that the overall level of the competitiveness of the business models of the studied airline companies is quite low, since there is not a single company in the most attractive high competitiveness area. Also, 6 out of 15 examined airlines are at a crisis stage of the development, which actualizes the need to develop a set of anti-crisis measures to further stabilize the competitive position.

\section{Conclusions}

The study conducted allowed to group and identify common methods for assessing the competitiveness of the enterprises, namely: matrix methods, methods based on the evaluation of goods and services, as well as methods based on the theory of effective competition, which proved unsuitable for assessing the competitiveness of the business models of the airline companies, because of the difficulties of calculating the integral index. Therefore, it was proposed own theoretical and methodological approach to managing the formation of the effective business model and diagnostics of the competitiveness of the business 


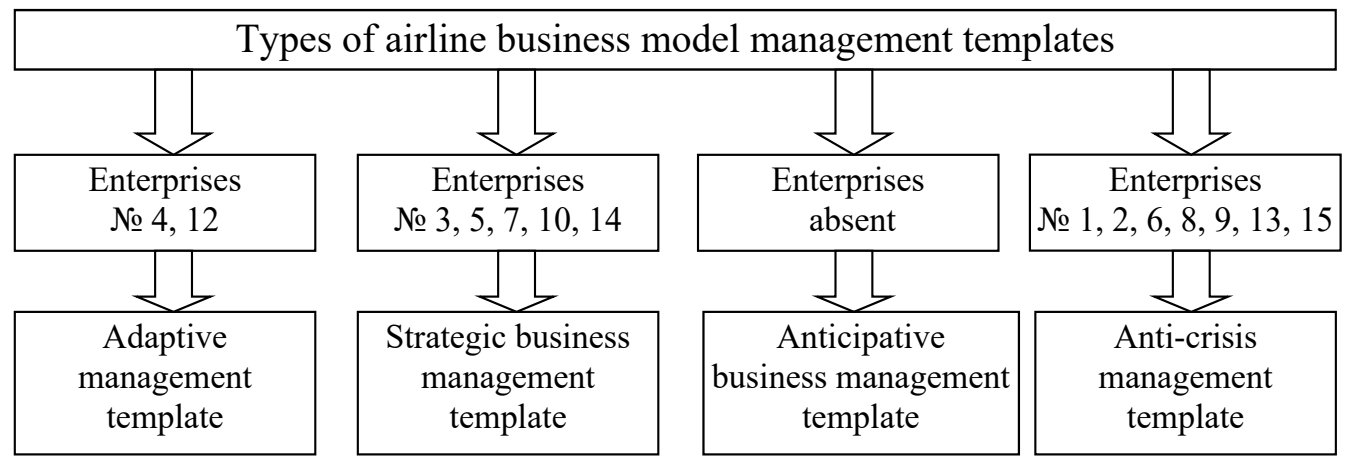

Figure 9. Types of business model management templates for the airline companies based on the results of the "competitive development matrix" construction

Source: designed by the author

models of the airline enterprises through the use of the dualistic system of the integrated indicators, which combined statistical and dynamic assessment systems. The first integral indicator provides a static assessment of the competitiveness of the airline company's business model compared to selected competitors, a reference company or average data for a particular market. The second integral indicator is responsible for the dynamic component and, accordingly, helps to evaluate a set of financial, managerial and marketing indices, which characterize the results of both basic and managerial business processes of the enterprise, taking into account the overall quality of business management processes. Which, according to the article, allowed to link such basic characteristics of competitiveness as comparability and fixation in time.

The prospect of the study should be the development of strategies to develop the competitiveness of the business models of the airline companies according to the obtained templates of their management.

\section{References:}

Ghorbalj, N. I., \& Sukhorsjka, U. R. (2012). Ocinjuvannja rivnja konkurentnykh perevagh ta konkurentospromozhnosti pidpryjemstva [Assessing the level of competitive advantage and competitiveness of the enterprise]. Visnyk Nacionaljnogho universytetu "Ljvivsjka politekhnika". Menedzhment ta pidpryjemnyctvo $v$ Ukrajini: etapy stanovlennja i problemy rozvytku, 748, 126-132.

Zotova, Je. V. (2012). Metodychni pidkhody do ocinky konkurentospromozhnosti pidpryjemstv [Methodical approaches to assessing the competitiveness of enterprises]. Ekonomika i upravlinnja, 2, 119-126.

Kabaljsjka, B. V. (2013). Metodologhichni aspekty kompleksnoji ocinky konkurentospromozhnosti pidpryjemstva [Methodological aspects of a comprehensive assessment of the competitiveness of the enterprise]. Nauka j ekonomika, 2, 129-134.

Kokura, K. V. (2013). Rozrobka ekonomiko-matematychnoji modeli ocinjuvannja konkurentospromozhnosti pidpryjemstva na zovnishnjomu rynku [Development of economic and mathematical model for assessing the competitiveness of the enterprise in foreign markets]. Ekonomichnyj prostir, 73, 185-193.

Kotvicjkyj, V. M. (2009). Ocinka rivnja konkurentospromozhnosti pidpryjemstva: teoretychnyj ta praktychnyj aspekty [Assessment of the level of competitiveness of the enterprise: theoretical and practical aspects]. Tekhnologhija i tekhnika drukarstva, 1-2, 96-103.

Miroshnyk, M. V., \& Kobjeljev, V. M. (2014). Rozrobka modeli ocinky rivnja konkurentospromozhnosti pidpryjemstva [Development of a model for assessing the level of competitiveness of the enterprise]. Visnyk Nacionaljnogho tekhnichnogho universytetu "KhPI". Serija: Tekhnichnyj proghres ta efektyvnistj vyrobnyctva, 32, 182-187.

Nykoljuk, O. M. (2011). Metodologhichni aspekty ocinjuvannja konkurentospromozhnosti pidpryjemstv [Methodological aspects of assessing the competitiveness of enterprises]. Visnyk Zhytomyrsjkogho nacionaljnogho aghroekologhichnogho universytetu, 2(2), 61-72.

Serghijenko, O. A., \& Tatar, M. S. (2012). Prostorovo-dynamichna ocinka ta analiz indykatoriv konkurentospromozhnosti pidpryjemstv [Spatial-dynamic assessment and analysis of indicators of enterprise competitiveness]. Biznes Inform, 4, 41-46.

Skoroboghatova, N. Je., \& Gherghelj, M. Ju. (2014). Modelj ocinky konkurentospromozhnosti promyslovogho pidpryjemstva [Model for assessing the competitiveness of an industrial enterprise]. Ekonomichnyj forum, 1 , 153-161.

Tranchenko, O. M. (2013). Konkurentospromozhnistj sub'jektiv pidpryjemnycjkoji dijaljnosti: sutnistj, metody ta kryteriji ocinky [Competitiveness of business entities: essence, methods and evaluation criteria]. Oblik i finansy, 3, 143-148. 
Shevchenko, I. Ju. (2018). Istorychna evoljucija ta suchasna interpretacija definiciji sutnosti kateghoriji "konkurentospromozhnistj pidpryjemstva avtomobilebuduvannja" [Historical evolution and modern interpretation of the definition of the essence of the category "competitiveness of the automotive industry"]. Biznes Inform, 1, 20-27.

Shevchenko, I. Ju. (2018). Konkurentnyj potencial pidpryjemstv avtomobilebuduvannja: sutnisna ta strukturna kharakterystyka [Competitive potential of automobile enterprises: essential and structural characteristics]. Ekonomika. Finansy. Pravo: shhomisjachnyj informacijno-analitychnyj zhurnal, 8, 34-37.

Shevchenko, I. Ju. (2018). Metodychni zasady ocinjuvannja konkurentospromozhnosti avtomobilebudivnykh pidpryjemstv u konteksti formuvannja derzhavnoji strateghiji rozvytku avtomobilebuduvannja [Methodical bases of estimation of competitiveness of automobile enterprises in the context of formation of the state strategy of development of automobile industry]. Visnyk Kyjivsjkogho nacionaljnogho universytetu tekhnologhij ta dyzajnu, 4(125), 49-61.

Shevchenko, O. O. (2013). Suchasni pidkhody do ocinky konkurentospromozhnosti pidpryjemstva [Modern approaches to assessing the competitiveness of the enterprise]. Visnyk Kyjivsjkogho nacionaljnogho universytetu tekhnologhij ta dyzajnu, 4, 136-139.

Shynkar, S. M. (2011). Ocinka konkurentospromozhnosti pidpryjemstva z vykorystannjam ghrafichnogho metodu [Assessment of the competitiveness of the enterprise using the graphical method]. Ekonomichna strateghija i perspektyvy rozvytku sfery torghivli ta poslugh, 2, 274-278.

Jackovyj, D. V. (2013). Suchasni metodyky ocinky konkurentospromozhnosti pidpryjemstva [Modern methods of assessing the competitiveness of the enterprise. Bulletin of socio-economic research]. Visnyk socialjnoekonomichnykh doslidzhenj, 4, 183-188. 